\title{
NOSTRADAMUS LITE - SELECTED SPECULATIONS AS TO THE FUTURE OF INTERNET JURISDICTION ${ }^{*}$
}

by

\author{
DAN JERKER B. SVANTESSON ${ }^{* *}$
}

This paper examines and analyses current trends in the field of Internet jurisdiction, including the troubling development of overly broad claims of 'scope of jurisdiction', the increasing interest in so-called geo-location technologies and the tendency of litigants targeting Internet intermediaries. A handful of recent key judgments from around the world are also analysed, and an effort is made to identify and present key projects and other initiatives currently dealing with the topic of Internet jurisdiction. Based on observations flowing from this analysis, a selection of speculations as to the future of Internet jurisdiction is presented.

It will be shown that while the topic of Internet jurisdiction is currently gaining an unprecedented degree of attention and, while progress is being made, there are several serious hurdles in relation to which we have seen little or no progress over the past 20 years. In addition, there are new dangerous trends emerging, adding to the concerns for the future direction of Internet jurisdiction.

\section{KEY WORDS}

Internet Jurisdiction, Scope of Jurisdiction, Europe, Australia, Internet Intermediaries, Territoriality, Geo-location Techniques

This article draws, and expands, upon some research findings presented in: D Svantesson, Private International Law and the Internet $3^{\text {rd }}$ Ed., Kluwer Law International, Alphen aan den Rijn (2016).

** dasvante@bond.edu.au, Professor and Co-Director, Centre for Commercial Law, Faculty of Law, Bond University (Australia). Visiting Professor, Faculty of Law, Masaryk University (Czech Republic). Researcher, Swedish Law \& Informatics Research Institute, Stockholm University (Sweden). Professor Svantesson is the recipient of an Australian Research Council Future Fellowship (project number FT120100583). The views expressed herein are those of the author and are not necessarily those of the Australian Research Council. 


\section{INTRODUCTION}

The topic of Internet jurisdiction is currently gaining an unprecedented degree of attention and, while progress is being made, there are several serious hurdles in relation to which we have seen little or no progress over the past 20 years. In addition, there are new dangerous trends emerging, adding to the concerns for the future direction of Internet jurisdiction.

This paper examines and analyses current trends in the field of Internet jurisdiction, including the troubling development of overly broad claims of 'scope of jurisdiction', the increasing interest in so-called geo-location technologies, the tendency of litigants targeting Internet intermediaries, the mismatch between 'oughts' and 'cans', the increase in value clashes and the serious implications of our overreliance on territoriality. As part of the discussion, a handful of recent key judgments from around the world are analysed, and based on observations flowing from this analysis, a selection of speculations are made as to the future of Internet jurisdiction.

For those members of the academic community who are particularly fearful of anything they perceive as based on an author's own views or thinking - something lacking objectivity - this article's scope will no doubt come across as threateningly subjective. However, the reality is that the aim here is simply to describe what I, subjectively, perceive as the most important current trends in the area that broadly can be referred to as Internet jurisdiction.

To set the scene for the discussion to come, the article opens with an effort to identify and present some illustrative key projects and other initiatives currently dealing with the topic of Internet jurisdiction, as the outcomes of those projects and initiatives are likely to shape important aspects of the future of Internet jurisdiction.

\section{INTERNET JURISDICTION - WHAT IS GOING ON?}

Since the field of Internet jurisdiction to date largely has been left to a rather organic and uncoordinated development, it is now time we cut through the thick undergrowth of inconsistent approaches that has developed and tidy up this area of law. This will no doubt be a daunting, tedious, and labour-intensive task. 
What is interesting and of no little significance is the fact that never before has so much attention been directed, around the world, at this area of law. Therefore, even though it becomes a rather mechanical presentation, I will here briefly bring attention to a small selection of relevant and particularly interesting projects and other initiatives that currently are seeking to address - or at a minimum, bring attention to - matters of Internet jurisdiction. If nothing else, this section showcases some of the activity in the field and should serve as a useful overview of some of the sources from which we may expect to see significant developments over the coming years.

We can here usefully start by focusing on the European context. Given a 2014 Communication from the Commission, it seems the European Union has the ambition to give attention to the issue of Internet governance, including to the topic of Internet jurisdiction. In this context, the Communication notes the significance of 'conflicts of laws and jurisdictions' and states that:

"The European Commission will launch an in-depth review of the risks, at international level, of conflicts of laws and jurisdictions arising on the Internet and assess all mechanisms, processes and tools available and necessary to solve such conflicts. All options for action at the Union or international level will subsequently be carefully considered, including possible legislative initiatives or additional guidelines as needed, subject to appropriate impact assessments. This work will build on existing policies." 1

I will have reason to return to other aspects of the work of the European Commission below.

It may also be emphasised that Internet jurisdiction is quite consistently an item on the agenda at the European Dialogue on Internet Governance (EuroDIG) meetings. ${ }^{2}$ For example, at the 2015 EuroDIG in Bulgaria, at least four sessions had a clear Internet jurisdiction aspect to them. ${ }^{3}$

1 European Commission 2014, Communication from the Commission to the European Parliament, the Council, the European Economic and Social Committee and the Committee of the Regions on Internet Policy and Governance (COM(2014) 072), 12 February 2014, viewed 3 June 2016,

$<$ http://eur-lex.europa.eu/legal-content/EN/TXT/PDF/? uri=CELEX:52014DC0072\&from $=E N>$.

2 See, e.g.: EuroDIG 2015, Messages from Sofia 4-5 June 2015: Shaping the Internet Together, viewed 3 June 2016,

$<$ http://www.eurodig.org/fileadmin/user_upload/eurodig_Sofia/EuroDIG_A5.pdf>.

3 EuroDIG 2015, Category: Sessions 2015, viewed 3 June 2016,

$<$ http://eurodigwiki.org/wiki/Category:Sessions_2015>. 
On the international level, the most significant developments can be expected to come from the work of the Hague Conference on Private International Law. In 1992, preparatory work on a new and ambitious convention was initiated by the Hague Conference on Private International Law. The previously proposed Convention, which was an initiative of the US government, was called the Hague Convention on Jurisdiction and Foreign Judgments in Civil and Commercial Matters, but was commonly referred to as the 'judgments project'.

Due to a range of factors, the wide scope and great ambitions of the 'judgments project' proved impossible at the time, and in late 2003, the 'judgments project' was replaced by a much narrower convention proposal, the 2005 Hague Convention on Choice of Court Agreements.

Importantly, in 2012, it was decided that work on the judgments project would recommence, and e-commerce is still within its proposed ambit. The Second Working Group Meeting on the Judgments Project was held at the end of February 2014. In March 2015, the Council on General Affairs and Policy of the Conference noted that the Working Group working on the judgments project had made significant progress and invited it to continue its work. ${ }^{4}$ The outcome of this work is found in the Report of the fifth meeting of the working group on the judgments project (26-31 October 2015) with a proposed draft text resulting from the meeting. ${ }^{5}$

In June 2015, UNESCO released its Internet study titled Keystones to Foster Inclusive Knowledge Societies: Access to Information and Knowledge, Freedom of Expression, Privacy and Ethics on a Global Internet. Importantly, it identified jurisdictional issues as one of the key challenges cutting across the areas included in the study. ${ }^{6}$

Aspects of the International Law Association's work are also relevant in our context. For example, one of its Committees focuses on Intellectual Property and Private International Law. Its objective is to:

Council on General Affairs and Policy of the Conference 2015, Conclusions and Recommendations Adopted by the Council, viewed 3 June 2016,

$<$ http://www.hcch.net/upload/wop/gap2015concl_en.pdf>.

5 Council on General Affairs and Policy of the Conference 2015, Report of the Fifth Meeting of the Working Group on the Judgments Project (26-31 October 2015) and Proposed Draft Text Resulting from the Meeting, viewed 3 June 2016,

$<$ http://www.hcch.net/upload/wop/gap2016pd07a_en.pdf>.

${ }^{6}$ UNESCO, Keystones to Foster Inclusive Knowledge Societies: Access to Information and Knowledge Freedom of Expression, Privacy, and Ethics on a Global Internet, pp. 77-78, viewed 3 June 2016, <http://unesdoc.unesco.org/images/0023/002325/232563E.pdf>. 
"propose a set of Guidelines on the basis of the current state of legal discussions at international level. The proposed Guidelines are expected to provide a set of recommendations to promote a more efficient resolution of cross-border IP disputes and provide a model for national and international legislative initiatives." 7

Importantly, the work of this Committee expressly considers the position of Internet intermediaries, which, as was emphasised above, is a key consideration in the context of Internet jurisdiction:

"In sharp contrast with the evolution of Internet law in most major industrialized countries that have adopted specific provisions regarding the (non) liability of Internet intermediaries the position of intermediaries has not been the subject of a similar attention from the perspective of private international law. However, the activities and services of those intermediaries having potentially global reach or impact pose particular challenges from the perspective of private international law (footnotes omitted)." 8

Another initiative that should be included here is the 'Internet \& Jurisdiction Project' under the Directorship of Mr de La Chapelle:

"The Internet $\mathcal{E}$ Jurisdiction Project is a platform for a structured, global multi-stakeholder dialogue process to address the tension between geographically defined national jurisdictions and the cross-border nature of the Internet in a constructive manner. [...] The Internet $\mathcal{E}$ Jurisdiction Project facilitates an evidence-based dialogue process. [...] Since 2012, hundreds of cases were curated in the dedicated IEJ database and subsequently crowd-ranked by the Observatory expert network, which supports the IEJ Project." 9

7 International Law Association, Washington Conference 2014, Intellectual Property and Private International Law, p. 2, viewed 3 June 2016,

<http://www.ila-hq.org/download.cfm/docid/33B8054F-F87D-4433-A1DC108BF6A08B68>.

8 International Law Association, Sofia Conference 2012, Intellectual Property and Private International Law, p. 16, viewed 3 June 2016,

<http://www.ila-hq.org/download.cfm/docid/59D49CFE-2AC0-4D74-92E82EF00AC116F9>.

9 Internet \& Jurisdiction Project n.d., Internet \& Jurisdiction Project: Structure, viewed 3 June 2016, <http://www.internetjurisdiction.net/about/structure/>. For the 2013/2014 Progress Report, see: Internet \& Jurisdiction Project 2014, Internet \& Jurisdiction: Progress Report 2013/2014, viewed 3 June 2016,

$<$ http://www.internetjurisdiction.net/wp-content/uploads/2015/01/Internet-Jurisdiction-

Project-Progress-Report-2013-14.pdf>. 
On a national level, there is also considerable interest in addressing the complications that Internet technology brings to the area of jurisdiction. In Australia, for example, the Attorney General's Department issued a Discussion Paper in 2012 resulting in a number of submissions. One of the areas given specific attention in the Discussion Paper was jurisdiction and the Internet. In particular, submissions were sought on the following questions: Do you think it is necessary to modernise jurisdictional rules in light of the advances in online and mobile technology and other developments? [...] Do you think the current law could better harness the opportunities presented by new technologies? ${ }^{10}$ However, the current state of the reform project is perhaps appropriately summarised by what is found on the Attorney-General's Department's website under the heading 'Private international law'. ${ }^{11}$ There, at the time of writing, we find reference to materials from 2012 as well as a broken hyperlink to the now abandoned Standing Council on Law and Justice. It consequently seems serious reform is some way off yet. ${ }^{12}$

Other activity in the field is exemplified by a comprehensive and detailed report published by the Center on Law and Information Policy at the Fordham University School of Law in 2013:

"The goal of this study is to identify the trends in the legal literature and key U.S. case law with respect to jurisdiction for claims arising out of Internet activity. Questions about jurisdiction arise in almost every Internet case and the legal rules and tests remain in flux in the United States and internationally. This report seeks to offer an objective and comprehensive survey of the literature and of key U.S. court decisions on Internet jurisdiction." 13

10 Attorney-General's Department n.d., Reducing Legal Complexity of Cross-Border Transactions and Relationships (Discussion Paper), p. 18.

11 Attorney-General's Department 2015, Private International Law, viewed 3 June 2016, $<$ http://www.ag.gov.au/Internationalrelations/PrivateInternationalLaw/Pages/default.aspx>.

12 Continuing looking specifically at Australia, the Australian Research Council has also invested in research on the topic of Internet jurisdiction by providing a so-called Future Fellowship, funding a four-year research project reassessing and re-evaluating how the concept of jurisdiction most appropriately can be applied in the Internet era characterised by cloud computing, Web 2.0 and geo-location technologies. That project aims to identify a set of core principles to govern jurisdictional claims over Internet conduct and produces a set of detailed model laws. See further: Bond University researcher recognised as one of Australia's best and brightest, 2012, 26 July 2012, viewed 3 June 2016,

$<$ https://bond.edu.au/news/44138/bond-university-researcher-recognised-one-australias-

best-and-brightest>. 
A second report was published dealing specifically with German scholarship and cases. ${ }^{14}$ Scholarship such as this is of great value in mapping out trends - trends that then can be analysed and structured.

Finally, it should be mentioned that a rather substantial number of conferences and other events have been organised lately dealing directly with the topic of Internet jurisdiction.

Obviously this selection is rather eclectic, and there are no doubt numerous other initiatives that reasonably could have been included. But even so, the above should be enough to highlight that there is currently a strong will to make real progress in the field of Internet jurisdiction.

\section{SIX CURRENT KEY CHALLENGES}

Having noted the considerable activity in the field of Internet jurisdiction, it is probably appropriate to pose the question: what are then the challenges for serious reform and improvement in this field? In answering this question, we could point to some of the eternal themes of the field, such as the contrast between, on the one hand, the 'borderless' or at least 'borderdisregarding' nature of the Internet, and the very 'border-dependent' nature of law, on the other hand. However, in the below, I have sought to focus on current trends that are more typical for the paradigm we are in at the moment.

\subsection{INCREASED LITIGATION AGAINST INTERNET INTERMEDIARIES} We all connect to the Internet via intermediaries (such as the telecommunications companies we contract with), and most of our online activities go via intermediaries such as Google or Bing search, shopping platforms such as eBay, and social media platforms such as Facebook. Thus, intermediaries are crucial both in the hardware and software context, and the fact that intermediaries play a central role in the Internet landscape is little more than a truism. However, the role they play frequently, and increasingly, puts them in the line of fire. They are obvious targets

13 Reidenberg, J et al 2013, Internet Jurisdiction: A Survey of Legal Scholarship Published in English and United States Case Law [30 June 2013] Fordham Law Legal Studies Research Paper No. 2309526. Available at SSRN: <http://ssrn.com/abstract=2309526> or $\langle$ http://dx.doi.org/10.2139/ssrn.2309526 >, viewed 3 June 2016.

14 Jaeger-Fine, D, Reidenberg, J, Debelak, J and Kovnot, J 2013, Internet Jurisdiction: A Survey of German Scholarship and Cases [30 June 2013] Fordham Law Legal Studies Research Paper No. 2309575. Available at SSRN: <http://ssrn.com/abstract=2309575> or <http://dx.doi.org/10.2139/ssrn.2309575>, viewed 3 June 2016. 
in litigation for several reasons, such as the fact that they typically are easy to identify, and have 'deep pockets'. Indeed, as noted in the European Commission's Digital Single Market Strategy:

"Platforms generate, accumulate and control an enormous amount of data about their customers and use algorithms to turn this into usable information. The growth of such data is exponential - 90\% of all data circulating on the Internet were created less than 2 years ago. Moreover, platforms have proven to be innovators in the digital economy, helping smaller businesses to move online and reach new markets. New platforms in mobility services, tourism, music, audiovisual, education, finance, accommodation and recruitment have rapidly and profoundly challenged traditional business models and have grown exponentially. The rise of the sharing economy also offers opportunities for increased efficiency, growth and jobs, through improved consumer choice, but also potentially raises new regulatory questions." ${ }^{15}$

The important role played by Internet intermediaries, the increasing pressure (such as the risk of bringing targeted in litigation, or otherwise being forced to monitor, delist, remove, block content) they are under, and the need for a clearer legal landscape were all recognized and articulated in a series of 2010 Organisation for Economic Co-operation and Development (OECD) documents. It is also emphasised, for example, by the European Commission, ${ }^{16}$ and in the 24 April 2014 NETmundial Multistakeholder Statement. ${ }^{17}$ And in a Report of the Special Rapporteur on the promotion and protection of the right to freedom of opinion and expression it was emphasised that:

"Holding intermediaries liable for the content disseminated or created by their users severely undermines the enjoyment of the right to freedom of opinion and expression, because it leads to self-protective and over-broad

15 European Commission 2015, 'Brussels, 6.5.2015 COM(2015) 192 final Communication from The Commission to the European Parliament, the Council, the European Economic and Social Committee and the Committee of the Regions: A Digital Single Market Strategy for Europe $\{\text { SWD(2015) } 100 \text { final }\}^{\prime}$, p. 11.

16 European Commission 2015, 'Brussels, 6.5.2015 COM(2015) 192 final Communication from The Commission to the European Parliament, the Council, the European Economic and Social Committee and the Committee of the Regions: A Digital Single Market Strategy for Europe $\{S W D(2015) 100 \text { final }\}^{\prime}$, p. 11.

17 NETmundial 2014, NETmundial Multistakeholder Statement, viewed 3 June 2016, $<$ http://netmundial.br/wp-content/uploads/2014/04/NETmundial-MultistakeholderDocument.pdf $>$. 
private censorship, often without transparency and the due process of the law." 18

Despite this, we seem to have some way to go before we arrive at a sensibly balanced framework for the circumstances under which Internet intermediaries are liable for content they are associated with. Yet some things seem to be beyond intelligent dispute. First of all, it is beyond intelligent dispute that certain types of content, such as child pornography materials, are indefensible, and Internet intermediaries can, and do, play an important role in the fight against such content. ${ }^{19}$

Second, while intermediaries have existed in various forms for a long time (consider e.g. newspapers, radio and TV broadcasters and even libraries), the role and function of Internet intermediaries is so fundamentally different to other types of intermediaries that they must be approached with fresh eyes free from the contamination of preconceived notions based on comparisons with the roles of other intermediaries.

Third, the diversity of types of Internet intermediaries excludes a onesize-fits-all approach. ${ }^{20}$

Fourth, it quite clearly does not lie in the interest of Internet intermediaries to become arbiters of "good taste" or lawfulness of thirdparty content in a general sense. ${ }^{21}$

Fifth, if a duty of ex-ante blocking or removal is to be imposed on Internet intermediaries, they are likely to, at least sometimes, be faced with deciding whether certain content is legal or illegal where it is questionable whether there are objective standards conclusively determining that question. ${ }^{22}$

18 United Nations Human Rights Council 2011, Report of the Special Rapporteur on the promotion and protection of the right to freedom of opinion and expression, Frank La Rue, A/HRC/17/27 (16 May 2011), p. 12, viewed 3 June 2016,

<http://www2.ohchr.org/english/bodies/hrcouncil/docs/17session/A.HRC.17.27_en.pdf>.

19 Google, for example, has "a global all-product ban against child pornography" (Whetstone, $\mathrm{R} 2007$, Free expression and controversial content on the web (14 November 2007), viewed 3 June 2016, <http://googleblog.blogspot.com.au/2007/11/free-expression-and-controversial.html>).

20 See further: OECD 2010, Workshop Summary: 'The Role of Internet Intermediaries in Advancing Public Policy Objectives', p. 4, viewed 3 June 2016, $<$ http://www.oecd.org/internet/ieconomy/45997042.pdf>.

21 See, e.g., Whetstone, R 2007, Free expression and controversial content on the web (14 November 2007), viewed 3 June 2016, <https://googleblog.blogspot.com.au/2007/11/free-expressionand-controversial.html>: "Google is not, and should not become, the arbiter of what does and does not appear on the web. That's for the courts and those elected to government to decide." 
Finally, as I have argued elsewhere, global blocking, de-listing or removal cannot reasonably be the default position in every case where an Internet intermediary is asked to block, de-list or remove content. ${ }^{23}$ This neatly brings us to the next topic I want to raise here, namely that of 'scope of jurisdiction'. However, before we go there, I want to stress my suspicion that we have so far only seen the beginning of the trend of Internet intermediaries being targets in litigation, and as there is no reason to think that the factors that make them 'suitable' targets for litigation will change, only sensible legal solutions are likely to improve the situation in the future.

\subsection{THE ISSUE OF 'SCOPE OF JURISDICTION'}

The Google Spain case is one of the most well-known examples of litigation directed at an Internet intermediary, but there are, of course, many others. ${ }^{24}$ One aspect of the Google Spain case that is particularly interesting is that the Court of Justice of the European Union (CJEU) was not asked to consider the geographical scope of the so-called 'right to be forgotten'. Google has taken the view that the decision is not global in reach. Consequently, they decided to extend each de-listing to all EU/European Free Trade Association ccTLDs. ${ }^{25}$ In sharp contrast, the Article 29 Working Party's $^{26}$ Guidelines $^{27}$ regarding the Google Spain decision emphasises that de-listing must apply to all relevant domains, including '.com'.28

Disagreements such as this relate to jurisdiction. But what form of jurisdiction? As is familiar, jurisdiction in private international law is typically divided into two categories: personal jurisdiction and subject-

22 Sartor, G 2013, 'Provider's Liability and the Right to Be Forgotten', in D Svantesson \& S Greenstein, (eds), Nordic Yearbook of Law and Informatics 2010-2012: Internationalisation of Law in the Digital Information Society, Ex Tuto Publishing, Copenhagen, pp. 101-137, at p. 111.

23 Svantesson, D 2015, 'Limitless borderless forgetfulness? Limiting the geographical reach of the "right to be forgotten", Oslo Law Review, vol. 2, no. 2, pp. 116-138.

24 Consider, e.g., Equustek Solutions Inc v. Jack (2014) BCSC 1063, and perhaps even the classic Yahoo! France case (Ligue contre le racisme et l'antisémitisme et Union des étudiants juifs de France c Yahoo! Inc et Société Yahoo! France and Yahoo! Inc v La Ligue Contre Le Racisme et l'Antisemitisme 433 F3d 1199 [9th Cir 2006]).

25 Fleischer, P 2014, Response to the Questionnaire addressed to Search Engines by the Article 29 Working Party regarding the implementation of the CJEU judgment on the "right to be forgotten" (31 July 2014), viewed 3 June 2016,

<https://docs.google.com/file/d/0B8syaai6SSfiT0EwRUFyOENqR3M/view?pli=1\&sle=true>.

For more on Google's actual implementation of the decision refer to its transparency report: Google n.d., European privacy requests for search removals, viewed 3 June 2016, <https://www.google.com/transparencyreport/removals/europeprivacy/?hl=en>.

The reference to 'ccTLDs' refers to 'country code top-level domains' such as .se, .no or .dk. 
matter jurisdiction. However, neither of those categories capture what we are dealing with here.

Thus, I argue that we need to recognise a third category of jurisdiction, what we can call 'scope of jurisdiction'. Scope of jurisdiction relates to the appropriate geographical scope of orders rendered by a court that has personal jurisdiction and subject-matter jurisdiction. ${ }^{29}$ This question has gained far less attention to date than have the other aspects of jurisdiction. However, it is a question that is increasing in importance and therefore is deserving of attention, and I predict it is a matter that will increase in prominence in the coming years. ${ }^{30}$

\subsection{GEO-LOCATION TECHNOLOGIES - FINALLY A 'HOT' TOPIC}

Despite a long history, such technologies have only recently gained widespread attention in literature. ${ }^{31}$ Indeed, geo-location, geo-identification, geo-blocking, geo-filtering, geo-targeting, or however we wish to refer to the technology used to pinpoint the geographical location of those active on the Internet, has made the remarkable journey of going from being ignored to being taken for granted - there has been no middle ground,

26 "The Article 29 Data Protection Working Party is composed of: a representative of the supervisory authority (ies) designated by each EU country; a representative of the authority (ies) established for the EU institutions and bodies; a representative of the European Commission." It was "set up under the Directive 95/46/EC of the European Parliament and of the Council of 24 October 1995 on the protection of individuals with regard to the processing of personal data and on the free movement of such data. It has advisory status and acts independently." European Commission 2015, Article 29 Working Party (11 September 2015), viewed 3 June 2016,

$<$ http://ec.europa.eu/justice/data-protection/article-29/index_en.htm>.

27 Those Guidelines were "designed to provide information as to how the DPAs assembled in the Working Party intend to implement the judgment of the CJEU in the case of 'Google Spain SL and Google Inc. v Agencia Española de Protección de Datos (AEPD) and Mario Costeja González' (C-131/12)." Article 29 Data Protection Working Party 2014, 'Guidelines on the implementation of the Court of Justice of the European Union judgment on "Google Spain and Inc. v. Agencia Española de Protección de Datos (AEPD) and Mario Costeja González" - C-131/12' (2014) WP225, p. 5.

28 Ibid, 9. This approach has recently been emphasised by the French data protection authority - the Commission Nationale de Informatique et Libertés (CNIL) - in a media release of 12 June 2015 stating, amongst other things, that: "CNIL considers that in order to be effective, delisting must be carried out on all extensions of the search engine and that the service provided by Google search constitutes a single processing. In this context, the President of the CNIL has put Google on notice to proceed, within a period of fifteen (15) days, to the requested delisting on the whole data processing and thus on all extensions of the search engine." CNIL 2015, CNIL orders Google to apply delisting on all domain names of the search engine, viewed 3 June 2016,

$<$ http://www.cnil.fr/english/news-and-events/news/article/cnil-orders-google-to-applydelisting-on-all-domain-names-of-the-search-engine/>.

29 See further: Svantesson, D 2016, 'Jurisdiction in 3D - "scope of (remedial) jurisdiction" as a third dimension of jurisdiction', Journal of Private International Law, vol. 12, no, 1, pp. 60-76.

30 A recent Canadian decision already deals with the matter in some detail. See: Equustek Solutions Inc v Google Inc [2015] BCCA 265. 
no period during which we can point to a gradual awakening to these technologies.

At the time of writing, the use of geo-location technologies is very much in the sights of the European Commission. The clearest articulation of this is found in the prominence of geo-location issues in the Digital Single Market Strategy for Europe issued in May 2015. Indeed, the prominence of geo-location issues is such that a special consultation on geo-location has been initiated. ${ }^{32}$ Thus, the fact that geo-location is now firmly in the limelight is undeniable. Yet, it must be mentioned that geo-location technologies are, as is discussed in more detail below, still not considered to the degree one may perhaps have expected. Remaining within the EU context, we can, for example, point to the 'scope of jurisdiction' debate that has occurred in the wake of the Google Spain - 'right to be forgotten' decision. The CJEU was, as noted above, silent on the geographical scope of the right to be forgotten, or more appropriately, the right to delisting. Much could be said about the clash between different views on scope of jurisdiction that has arisen, but for our purposes here, the most interesting aspect is the fact that the debate has become so focused on toplevel domains at the expense of geo-location. This lends itself to an important observation: the use of geo-location technologies can be seen to be subjected to a two-front attack within the European Union. On the one hand, it seems that the European Commission views geo-

31 For some of the relatively early commentators see, e.g.: Trzaskowski, J 2005, Legal Risk Management in Electronic Commerce, Ex Tuto Publishing, Copenhagen; Krog, G 2005, 'Jurisdiksjon og Avgrensning av Internett's Kolliderende Handlingsuniverser', in G Krog \& A Bekken (eds), Yulex 2005, Institutt for Rettsinformatikk, Oslo; Spang-Hanssen, H 2004 , Cyberspace $\mathcal{E}$ international law on jurisdiction, DJØF Publishing, Copenhagen and Geist, MJ2001, 'Is There a There There? Towards Greater Certainty for Internet Jurisdiction', Berkeley Technology Law Journal, vol. 16, p. 1345. See also, 'Developments in the Law: The Law of Media' 2007, Harvard Law Review, vol. 120, no. 4, pp. 990-1066, pp. 1040-1041 and Goldsmith, J and $\mathrm{Wu}, \mathrm{T}$ 2006, Who Controls the Internet? Illusions of a Borderless World, Oxford University Press, New York. For examples of important, more recent, comments on geo-location technologies, see: Trimble, M, 'The Future of Cybertravel: Legal Implications of the Evasion of Geolocation', Fordham Intellectual Property, Media E Entertainment Law Journal, vol. 22, p. 567; and, King, KF 2011, 'Personal jurisdiction, Internet Commerce, and Privacy: The Pervasive Legal Consequences of Modern Geolocation Technologies', Albany Law Journal of Science and Technology, vol. 21, p. 61. All these papers have been highly valuable for the work on this chapter.

32 "The consultation on geo-blocking and other forms of geographically-based restrictions will gather opinions on unjustified commercial barriers which prevent from buying and selling products and services within the EU. It covers, for example, customers who are charged different prices or offered a different range of goods depending on where they live, but it does not cover copyright-protected content and content licensing practices." (European Commission 2015, Press release: Have your say on geo-blocking and the role of platforms in the online economy Brussels, 24 September 2015, viewed 3 June 2016,

$<$ http://europa.eu/rapid/press-release_IP-15-5704_en.htm>). 
location as an obstacle to the desired Digital Single Market, and on the other hand, the use of geo-location is being ignored (and presumably seen as inadequate) in the scope of jurisdiction debate that has followed the mentioned Google Spain case. Both these actions clearly undermine the use of geo-location technologies.

More generally, in earlier Internet commentaries ${ }^{33}$ and case law, ${ }^{34}$ it was frequently said to be impossible to pinpoint the geographical location of those active on the Internet. Indeed, the impossibility of linking those active on the Internet to a geographical location was seen as a distinctive feature of the Internet. ${ }^{35}$ If ever true, the development of the Internet has now rendered these statements obsolete, and despite the two-front European attack on geo-location, my prediction is that the impact, and use, of such technologies will only increase in the foreseeable future; and so will, of course, the circumvention of such technologies.

\subsection{INCREASED NUMBER OF VALUE-CLASHES}

Given the very nature of Internet communications, it has always been the case that such communications may result in clashes of values. Perhaps the most well-known such clash can be seen in the transatlantic dispute in the Yahoo! case. ${ }^{36}$ Put in the fewest of words, there French concerns regarding the auctioning of Nazi materials clashed with US conceptions of freedom of speech.

Seeking to predict the future, I suspect that we will see more rather than less of such clashes in the years to come. After all, we are seeing more and more countries becoming serious Internet users -Internet usage is no longer an exclusive Western developed world domain. And at the same time, we are seeing little by way of harmonisation of substantive law in the relevant fields in which we see jurisdictional issues arise.

But even leaving aside the value clashes that we may see as a result of more countries becoming Internet users, in the CJEU's Safe Harbour

33 See, e.g., Johnson, D and Post, D 1996, 'Law and Borders - The Rise of Law in Cyberspace', Stanford Law Review, vol. 48, p. 1367. See also more recent works, such as: Fawcett, J et al 2005, International Sale of Goods in the Conflict of Laws, Oxford University Press, Oxford, p. 494.

34 See, e.g., American Libraries Association v Pataki 969 F Supp 160, 170 (SDNY, 1997).

35 See, e.g., Cobb, P et al 2000, 'Taxing Internet Transactions', University of Pennsylvania Journal of International Economic Law, vol. 21, p. 671.

36 Ligue contre le racisme et l'antisémitisme et Union des étudiants juifs de France c Yahoo! Inc et Société Yahoo! France and Yahoo! Inc v La Ligue Contre Le Racisme et l'Antisemitisme 433 F3d 1199 (9th Cir 2006). 
decision of October 2015, we were recently reminded of just how big the legal attitude gaps are also between relatively similar countries. ${ }^{37}$

These value clashes can be addressed in a number of ways, most of which are seriously damaging. For example, we could start searching for the lowest common denominator, but such a race to the strictest laws would seriously harm the Internet's usefulness. Alternatively, we could fragment the Internet into smaller components such as national Internets accessible only within defined geographical regions (such as States) each of which would be governed only by the applicable law of that region. However, that would, of course, mean the end of the Internet as we know it. A better solution would naturally be to harmonise all substantive laws. The only problem with such an approach is that it is entirely unrealistic. A slightly more realistic, yet still herculean, task is to create uniform rules, whether through an international agreement or other means, allocating jurisdiction so as to avoid value clashes.

In the end, my prediction is that the most realistic, and currently most fruitful, path forward is to aim for what I elsewhere have called 'jurisdictional interoperability'. ${ }^{38}$ We need to start working towards ironing out the most serious value clashes by building on the substantive law of existing human rights frameworks, trade law instruments etc, at the same time as we seek to improve our laws used to allocate jurisdiction.

\subsection{INCREASING MISMATCH BETWEEN 'OUGHTS' AND 'CANS'}

In one of his interesting papers, von der Pfordten reminds us of the wellknown principle 'ought implies can', ascribed to Immanuel Kant. ${ }^{39}$ Unfortunately, while not unique to the online environment, it seems that there is such a serious mismatch between 'oughts' and 'cans' in the online environment that this principle is not adhered to in the slightest.

When active online, we expose ourselves to the laws of many different states and we 'ought' to, of course, abide by all those laws. At the same time most Internet users would struggle to properly assess which states' laws apply to them in any given situation. Further, even where an Internet user

37 C-362/14 (Schrems).

38 See: Svantesson, D 2015, 'The holy trinity of legal fictions undermining the application of law to the global internet', International Journal of Law and Information Technology, vol. 23, no. 3, pp. 1-16.

39 von der Pfordten, D 2015, 'On Obligations, Norms and Rules' in M Araszkiewicz et al (eds) 2015, Problems of Normativity, Rules and Rule-Following, Springer International, Switzerland, p. 168. 
manages to ascertain which states' laws she ought to abide by, getting access to all those foreign laws, and understanding those laws, will be an unsurmountable task. Indeed, as noted by Reed, 'Ignorance of foreign law is not just common in cyberspace; it is inevitable. ${ }^{.40} \mathrm{I}$ discuss these issues at some depth in an article published in the International Journal of Law and Information Technology. ${ }^{41}$ For our purposes here, it suffices to note that this disturbing mismatch between 'oughts' and 'cans' is a characteristic, but undesirable, feature of our current paradigm, and that it is difficult to see how we are going to move beyond it. Looking towards the future, it is likely to be an issue we struggle with for quite some time, and again, I suspect that the path forward is to be found in the goal of 'jurisdictional interoperability'.

\subsection{OUR ATTACHMENT TO TERRITORIALITY - THE GREATEST OBSTACLE}

The focus on territory runs like a fil rouge throughout contemporary private, and public, international law. But its history is long: 'From ancient times a person was subject to the law of his tribe. This law followed the person wherever he moved. However, over time, both the influence of and the connection to the tribe faded. The principle of personality weakened and the principle of territory grew stronger. ${ }^{42}$ In other words, territoriality had come to prominence already at the fall of tribal society.

It is not my ambition here to provide a detailed history of the concept of territoriality. ${ }^{43}$ However, it deserves to be noted that the concept of territoriality we work with today is linked to its historical origins through a steady stream of endorsements by courts, legislators, policymakers and scholars. ${ }^{44}$

40 Reed, C 2012, Making Laws for Cyberspace, Oxford University Press, Oxford, p. 71.

${ }^{41}$ Svantesson, D 2015, 'The holy trinity of legal fictions undermining the application of law to\$the global internet', International Journal of Law and Information Technology, vol. 23, no. 3, pp. 1-16.

42 Konow, BR 2013, 'Observations on some points of contact between private and public international law in Sweden' in P Lindskoug et al (eds), Essays in Honour of Michael Bogdan, Jurisförlaget I Lund, Lund, p. 207.

43 See, instead, e.g.: Ryngaert, C 2015, Jurisdiction in International Law, 2nd edn, Oxford University Press, Oxford, pp. 50-62.

44 See, e.g.: Mills noting how "[t]he idea of territoriality was expressed, for example, in the first two 'maxims' of the Dutch eighteenth century private international law scholar Ulrich Huber" (Mills, A 2014, 'Rethinking Jurisdiction in International Law', The British Yearbook of International Law, vol. 84, no. 1, pp. 187-239, at p. 202). 
In some areas of law, territoriality is, if possible, even more pronounced than generally is the case. Looking at public international law, it has been noted that '[e]nforcement jurisdiction is, in international law, almost exclusively territorial'. ${ }^{45}$ Turning focus to private international law, in the context of intellectual property, the focus on territoriality is, typically, also strongly emphasised. As noted by Trimble:

"The principle of territoriality of IP rights, which permeates IP laws at all levels, influences the design and application of conflict of laws rules. [...] It is an extension of the territoriality principle that countries typically select the rule of lex loci protectionis (the law of the protecting country) or lex loci delicti (the law of the place of tort) for the choice of law applicable to infringements of IP rights." 46

While all of the above points to the strong position held by the principle of territoriality, there is a clearly increasing recognition that strict territoriality is ill-equipped for today's modern society. ${ }^{47}$ This is particularly so given that society of today is characterised by constant, fluid and substantial cross-border interaction, not least via the Internet. In fact, in the Internet context, a strict application of the territoriality principle is quite simply both unworkable and destructive. Consider, for example, how cross-border data communications often transit servers in States located between the sender and the receiver. It is an undisputable fact that

45 Mills, A 2014, 'Rethinking Jurisdiction in International Law', The British Yearbook of International Law, vol. 84, no. 1, pp. 187-239, at p. 195. See also: Ryngaert, C 2015, Jurisdiction in International Law, 2nd edn, Oxford University Press, Oxford, at p. 195.

46 Trimble, M 2014-2015, 'Advancing National Intellectual Property Policies in a Transnational Context', Maryland Law Review, vol. 74, pp. 231-232 (internal footnotes omitted).

47 See e.g.: Ryngaert, C 2015, Jurisdiction in International Law, 2nd edn, Oxford University Press, Oxford; Mills, A 2014, 'Rethinking Jurisdiction in International Law', The British Yearbook of International Law, vol. 84, no. 1, pp. 187-239; Slaughter, A 2006, 'The Future of International Law Is Domestic (or, The European Way of Law)', Harvard International Law Journal, vol. 47, p. 327; Berman, PS 2012, Global Legal Pluralism: A Jurisprudence of Law beyond Borders, Cambridge University Press, Cambridge; Oster, J 2012, 'Rethinking Shevill. Conceptualising the EU private international law of Internet torts against personality rights', International Review of Law, Computers E Technology, vol. 26, nos. 2-3, pp. 113-128; Schultz,T 2008, 'Carving up the Internet: Jurisdiction, Legal Orders, and the Private/Public International Law Interface', The European Journal of International Law, vol. 19, no. 4; Magnusson Sjöberg, C 2012, Rättens internationalisering i .. det digitala informationssamhället - Folkrätt och rättsinformatik, in R Stern \& I Österdahl (eds), Folkrätten i svensk rätt, Liber AB, Stockholm; and somewhat more carefully, Buxbaum, HL 2009, 'Territory, Territoriality, and the Resolution of Jurisdictional Conflict', American Journal of Comparative Law, vol. 57, p. 674 noting how: "[t]he use of territoriality as a mechanical standard used to link particular conduct with a particular country's law rightly rejected - must be distinguished from the use of territoriality as an expression of a specific understanding about fairness and legitimacy in cross-border regulation." 
during such a journey, data is temporarily located in the territory of the States other than the State of the sender and the State of the receiver. Under a strict application of the territoriality principle, the States of the transit servers could claim jurisdiction.

Thus, for example, where a person in State A sends an e-book to a person in State C, she may be exposed to the jurisdiction of State B if the e-book's journey happens to pass through State B (a fact that the sender may, of course, not be able to know in advance). If the content of the e-book is illegal in State B, the sender may, with no warning or real possibility to predict it, violate State B's law. Further, the owner of the server in State B may also be violating that State's laws. Such a situation is clearly undesirable, and several examples can be found of legal solutions put in place to avoid this destructive impact of a strict application of the territoriality principle. ${ }^{48}$ In light of this, the step to accepting that data being (temporarily and/randomly) stored on a server within a State, for example, due to a multistate cloud computing arrangement, should not always give that State jurisdiction over the data, may not be so dramatic.

In light of this, it is unsurprising that we are already seeing the supreme position of the territoriality principle eroding. In his interesting article 'Rethinking Jurisdiction in International Law', Mills highlights:

"The fact that these connecting factors are used and widely accepted in private international law itself suggests that the treatment of territory and nationality as discrete grounds for jurisdiction in traditional formulations of international law jurisdiction is too restrictive. The practice of states instead supports the idea that jurisdiction may be based on a flexible combination of both territorial and personal connecting factors - connections between a person and a place which do not depend on nationality, such as domicile or habitual residence." ${ }^{49}$

48 Consider, e.g., Article 4(1)(c) of Directive 95/46/EC of the European Parliament and of the Council of 24 October 1995 on the protection of individuals with regard to the processing of personal data and on the free movement of such data OJ (L 281): "[T]he controller is not established on Community territory and, for purposes of processing personal data makes use of equipment, automated or otherwise, situated on the territory of the said Member State, unless such equipment is used only for purposes of transit through the territory of the Community." (emphasis added).

49 Mills, A 2014, 'Rethinking Jurisdiction in International Law', The British Yearbook of International Law, vol. 84, no. 1, pp. 187-239, at p. 207. 
Another example of private international law thinking going beyond territoriality is found in the 'centre of interests' or 'centre of gravity' test. While this test most famously, in recent times, was employed by the Court in the eDate case, ${ }^{50}$ Oster emphasises that this test is not a recent discovery and points to its use in the US, Canada and by the House of Lords. ${ }^{51}$ Furthermore, he correctly links the test to Savigny's 'seat of the legal relationship'. ${ }^{52}$

Importantly, Oster also draws attention to the fact that the adoption of the "centre of interests" test in the eDate case was made necessary by the failure of current - territoriality-focused - connections tests such as the 'place where the information has been published', which in Oster's accurate assessment 'is rendered almost valueless with a view to the global accessibility of online publications': ${ }^{53}$

"Instead of a determination based on objective facts such as physical publication of a newspaper as under Shevill, the 'centre of gravity of the conflict' doctrine introduces an evaluating interest analysis considering different criteria in order to establish the appropriate forum most suitable for the interests of all the parties, that is, essentially the most convenient or 'natural' forum." 54

At any rate, whatever the status of the territoriality principle de lege lata, it is unsustainable as the jurisprudential core of our thinking on jurisdiction de lege ferenda. In light of this, I have advanced the following jurisprudential framework for jurisdiction - consisting of three core principles:

"In the absence of an obligation under international law to exercise jurisdiction, a State may only exercise jurisdiction where:

50 eDate Advertising GmbH $v$ X (C-509/09) and Olivier Martinez and Robert Martinez $v$ MGN Limited (C-161/10).

51 Oster, J 2012, 'Rethinking Shevill. Conceptualising the EU private international law of Internet torts against personality rights', International Review of Law, Computers $\mathcal{E}$ Technology, vol. 26, nos. 2-3, pp. 113-128, at p. 120.

52 Oster, J 2012, 'Rethinking Shevill. Conceptualising the EU private international law of Internet torts against personality rights', International Review of Law, Computers E Technology, vol. 26, nos. 2-3, pp. 113-128, at p. 120.

53 Oster, J 2012, 'Rethinking Shevill. Conceptualising the EU private international law of Internet torts against personality rights', International Review of Law, Computers $\mathcal{E}$ Technology, vol. 26, nos. 2-3, pp. 113-128, at p. 122.

54 Oster, J 2012, 'Rethinking Shevill. Conceptualising the EU private international law of Internet torts against personality rights', International Review of Law, Computers $\mathcal{E}$ Technology, vol. 26, nos. 2-3, pp. 113-128, at p. 121. 
(1) there is a substantial connection between the matter and the State seeking to exercise jurisdiction;

(2) the State seeking to exercise jurisdiction has a legitimate interest in the matter; and

(3) the exercise of jurisdiction is reasonable given the balance between the State's legitimate interests and other interests." 55

It is this jurisprudential framework I envisage as the starting point for a new paradigm for jurisdiction.

\section{CONCLUDING REMARKS}

The discussion above can clearly be criticised as being too brief, too sketchy and too diverse. Such criticism would not be entirely baseless. At the same time, it must be remembered that the article was written with a rather humble goal in mind; it is to provide a snapshot of some of the key challenges we are facing currently in the context of Internet jurisdiction. Such a snapshot may be useful as an overview pointing to further readings, and it may in fact also serve as a historical record of what the challenges looked like at the start of 2016.

In any case, turning to the conclusions that can be drawn from the above, first, attention was brought to the fact that Internet jurisdiction issues currently are attracting an unprecedented level of attention. Second, the concerns stemming from the tendency of litigants targeting Internet intermediaries were discussed, and it was concluded that we have so far only seen the beginning of the trend of Internet intermediaries being target in litigation; and as there is no reason to think that the factors that make them 'suitable' targets for litigation will change, only sensible legal solutions are likely to improve the situation in the future. Third, focus was placed on the troubling development of overly broad claims of 'scope of jurisdiction', and the prediction was made that this issue will increase in prominence in the coming years. Fourth, we turned to the increasing interest in so-called geo-location technologies, and it was suggested that the impact, and use, of such technologies will only increase in the foreseeable future. The fifth issue addressed was the serious mismatch between 'oughts' and 'cans' in the online environment. In this

55 Svantesson, D, 'A New Jurisprudential Framework for Jurisdiction: Beyond the Harvard Draft', American Journal of International Law Unbound, vol. 109, pp. 69-74. 
context, I had to conclude that this disturbing mismatch is a characteristic, but undesirable, feature of our current paradigm, and that it is difficult to see how we are going to move beyond it. Finally, and most importantly, attention was brought to how our attachment to 'territoriality' represents the biggest obstacle for real progress in the field of Internet jurisdiction.

\section{LIST OF REFERENCES}

Article 29 Data Protection Working Party 2014, 'Guidelines on the implementation of the Court of Justice of the European Union judgment on 'Google Spain and Inc. v. Agencia Española de Protección de Datos (AEPD) and Mario Costeja González' - C-131/12' (2014) WP225

Attorney-General's Department 2012, 'Reducing Legal Complexity of CrossBorder Transactions and Relationships' (Discussion Paper).

Attorney-General's Department 2015, Private International Law, viewed 25 April 2016,

<https://www.ag.gov.au/Internationalrelations/PrivateInternationalLaw/ Pages/default.aspx>.

Berman, PS 2012, Global Legal Pluralism: A Jurisprudence of Law beyond Borders, Cambridge University Press, Cambridge.

'Bond University researcher recognised as one of Australia's best and brightest' 2012 (26 July 2012)

$<$ https://bond.edu.au/news/44138/bond-university-researcher-

recognised-one-australias-best-and-brightest>.

Buxbaum, HL 2009, 'Territory, Territoriality, and the Resolution of Jurisdictional Conflict', American Journal of Comparative Law, vol. 57, p. 674.

'CNIL orders Google to apply delisting on all domain names of the search engine' n.d., viewed 25 April 2016, <http://www.cnil.fr/english/news- 
and-events/news/article/cnil-orders-google-to-apply-delisting-on-alldomain-names-of-the-search-engine/>.

Cobb, P et al 2000, 'Taxing Internet Transactions', University of Pennsylvania Journal of International Economic Law, vol. 21, p. 671.

Communication from the Commission to the European Parliament, the Council, the European Economic and Social Committee and the Committee of the Regions on Internet Policy and Governance 2014 (COM(2014) 072) 12 February 2014, viewed 25 April 2016, <http://eur-lex.europa.eu/legalcontent/EN/TXT/PDF/?uri=CELEX:52014DC0072\&from=EN>.

Council on General Affairs and Policy of the Conference 2015, Conclusions and Recommendations Adopted by the Council, viewed 25 April 2016, $<$ http://www.hcch.net/upload/wop/gap2015concl_en.pdf>.

'Developments in the Law: The Law of Media' 2007, Harvard Law Review, vol. 120, no. 4, pp. 990-1066, pp. 1040-1041.

EuroDIG 2015a, Messages from Sofia 4-5 June 2015: Shaping the Internet Together, viewed 25 April 2016, $<$ http://www.eurodig.org/fileadmin/user_upload/eurodig_Sofia/EuroDI G_A5.pdf>.

EuroDIG 2015b, Category: Sessions 2015, viewed 25 April 2016, $<$ http://eurodigwiki.org/wiki/Category:Sessions_2015>.

European Commission 2015a, Article 29 Working Party (11 September 2015), viewed 25 April 2016, $<$ http://ec.europa.eu/justice/data-protection/article-29/index_en.htm>.

European Commission 2015b, Press release: Have your say on geo-blocking and the role of platforms in the online economy, Brussels, 24 September 2015, viewed 25 April 2016, <http://europa.eu/rapid/press-release_IP-155704_en.htm>. 
European privacy requests for search removals n.d., viewed 25 April 2016, $<$ https://www.google.com/transparencyreport/removals/europeprivacy/? $\mathrm{hl}=\mathrm{en}>$.

Fawcett, J et al 2005, International Sale of Goods in the Conflict of Laws, Oxford University Press, Oxford.

Final Communication from The Commission to the European Parliament, the Council, the European Economic and Social Committee and the Committee of the Regions: A Digital Single Market Strategy for Europe 2015 (Brussels, 6.5.2015 COM(2015) 192) \{SWD(2015) 100 final $\}$.

Fleischer, P 2014, 'Response to the Questionnaire addressed to Search Engines by the Article 29 Working Party regarding the implementation of the CJEU judgment on the 'right to be forgotten" (31 July 2014), viewed 25 April 2016,

<https://docs.google.com/file/d/0B8syaai6SSfiT0EwRUFyOENqR3M/vie $\mathrm{w}$ ?pli=1\&sle=true $>$.

Geist, M 2001, 'Is There a There There? Towards Greater Certainty for Internet Jurisdiction', Berkeley Technology Law Journal, vol. 16, p. 1345.

Goldsmith, J and $\mathrm{Wu}, \mathrm{T}$ 2006, Who Controls the Internet? Illusions of a Borderless World, Oxford University Press, New York.

International Law Association 2012, Intellectual Property and Private International Law (Sofia Conference), viewed 25 April 2016, <http://www.ila-hq.org/download.cfm/docid/59D49CFE-2AC0-4D7492E82EF00AC116F9>.

International Law Association 2014, Intellectual Property and Private International Law (Washington Conference), viewed 25 April 2016, $<$ http://www.ila-hq.org/download.cfm/docid/33B8054F-F87D-4433A1DC108BF6A08B68>. 
Internet \& Jurisdiction Project: Structure 2014,

$<$ http://www.internetjurisdiction.net/about/structure/>.

Jaeger-Fine, D, Reidenberg, J, Debelak, J and Kovnot, J 2013, 'Internet Jurisdiction: A Survey of German Scholarship and Cases' [30 June 2013] Fordham Law Legal Studies Research Paper No. 2309575. Available at SSRN: $<$ http://ssrn.com/abstract $=2309575>$ or $<$ http://dx.doi.org/10.2139/ssrn.2309575>, viewed 25 April 2016.

Johnson, D \& Post, D 1996, ‘Law and Borders - The Rise of Law in Cyberspace', Stanford Law Review, vol. 48, p. 1367.

King, KF 2011, 'Personal jurisdiction, Internet Commerce, and Privacy: The Pervasive Legal Consequences of Modern Geolocation Technologies', Albany Law Journal of Science and Technology, vol. 21, p. 61.

Konow, BR 2013, 'Observations on some points of contact between private and public international law in Sweden' in P Lindskoug et al (eds), Essays in Honour of Michael Bogdan, Jurisförlaget I Lund, Lund, Sweden.

Krog, G 2005, 'Jurisdiksjon og Avgrensning av Internett's Kolliderende Handlingsuniverser', in G Krog \& A Bekken (eds), Yulex 2005, Institutt for Rettsinformatikk, Oslo, Norway.

Magnusson Sjöberg, C 2012, Rättens internationalisering i det digitala informationssamhället - Folkrätt och rättsinformatik, in R Stern \& I Österdahl (eds), Folkrätten i svensk rätt, Liber AB, Stockholm.

Mills, A 2014, 'Rethinking Jurisdiction in International Law', The British Yearbook of International Law, vol. 84, no. 1, pp. 187-239.

NETmundial 2014, NETmundial Multistakeholder Statement, viewed 25 April 2016, <http://netmundial.br/wp-content/uploads/2014/04/NETmundialMultistakeholder-Document.pdf>. 
OECD 2010, Workshop Summary: 'The Role of Internet Intermediaries in Advancing Public Policy Objectives'

<http://www.oecd.org/internet/ieconomy/45997042.pdf >.

Oster, J 2012, 'Rethinking Shevill. Conceptualising the EU private international law of Internet torts against personality rights', International Review of Law, Computers \& Technology, vol. 26, nos. 2-3, pp. 113-128.

Reed, C 2012, Making Laws for Cyberspace, Oxford University, Oxford.

Reidenberg, J et al 2013, 'Internet Jurisdiction: A Survey of Legal Scholarship Published in English and United States Case Law' [30 June 2013] Fordham Law Legal Studies Research Paper No 2309526. Available at SSRN: <http://ssrn.com/abstract=2309526> or <http://dx.doi.org/10.2139/ssrn.2309526>, viewed 25 April 2016.

Report of the Fifth Meeting of the Working Group on the Judgments Project (26-31 October 2015) and Proposed Draft Text Resulting from the Meeting, viewed 25 April 2016,

<http://www.hcch.net/upload/wop/gap2016pd07a_en.pdf>.

Ryngaert C 2015, Jurisdiction in International Law, 2nd edn, Oxford University Press, Oxford.

Sartor, G 2013, 'Provider's Liability and the Right to Be Forgotten', in D Svantesson \& S Greenstein, (eds), Nordic Yearbook of Law and Informatics 2010-2012: Internationalisation of Law in the Digital Information Society, Ex Tuto Publishing, Copenhagen.

Schultz, T 2008, 'Carving up the Internet: Jurisdiction, Legal Orders, and the Private/Public International Law Interface', The European Journal of International Law, vol. 19, no. 4. 
Slaughter, A 2006, 'The Future of International Law Is Domestic (or, The European Way of Law)', Harvard International Law Journal, vol. 47, p. 327.

Spang-Hanssen, H 2004, Cyberspace \& international law on jurisdiction, DJØF Publishing, Copenhagen.

Svantesson, D 2015a, 'Limitless borderless forgetfulness? Limiting the geographical reach of the 'right to be forgotten", Oslo Law Review, pp. 116-138.

Svantesson, D 2015b, 'The holy trinity of legal fictions undermining the application of law to the global internet', International Journal of Law and Information Technology, pp. 1-16.

Svantesson, D 2015c, 'A New Jurisprudential Framework for Jurisdiction: Beyond the Harvard Draft', American Journal of International Law Unbound, vol. 109, pp. 69-74.

Svantesson, D 2016, 'Jurisdiction in 3D - 'scope of (remedial) jurisdiction' as a third dimension of jurisdiction', Journal of Private International Law, pp. 60-76.

Trimble, M 2012, 'The Future of Cybertravel: Legal Implications of the Evasion of Geolocation', Fordham Intellectual Property, Media E Entertainment Law Journal, vol. 22, p. 567.

Trimble, M 2014-2015, 'Advancing National Intellectual Property Policies in a Transnational Context', Maryland Law Review, vol. 74, pp. 231232.Trzaskowski, J 2005, Legal Risk Management in Electronic Commerce, Ex Tuto Publishing, Copenhagen.

UNESCO 2015, Keystones to Foster Inclusive Knowledge Societies: Access to Information and Knowledge Freedom of Expression, Privacy, and Ethics on a Global Internet, viewed 25 April 2016, 
<http://unesdoc.unesco.org/images/0023/002325/232563E.pdf>.

United Nations Human Rights Council 2011, Report of the Special Rapporteur on the promotion and protection of the right to freedom of opinion and expression, Frank La Rue, A/HRC/17/27 (16 May 2011), viewed 25 April 2016,

<http://www2.ohchr.org/english/bodies/hrcouncil/docs/17session/A.HR C.17.27_en.pdf>.

von der Pfordten, D 2015, 'On Obligations, Norms and Rules' in M Araszkiewicz et al (eds) 2015, Problems of Normativity, Rules and Rule-Following, Springer International, Cham, Switzerland.

Whetstone, R 2007, Free expression and controversial content on the web (14 November 2007), viewed 25 April 2016,

$<$ https://googleblog.blogspot.com.au/2007/11/free-expression-andcontroversial.html>. 